\title{
ISLAM AS A CULTURAL CAPITAL IN INDONESIA AND THE MALAY WORLD A Convergence of Islamic Studies, Social Sciences and Humanities
}

\author{
M. Amin Abdullah \\ UIN Sunan Kalijaga, Yogyakarta - Indonesia | aminabdullah53@gmail.com
}

\begin{abstract}
The phenomenon of socio-political-religious life in the Middle East is a complete contrast to the sociopolitical-religious life in Southeast Asia, particularly in Indonesia and in Malay world in general. The changing of socio-political leadership in Indonesia from the New Order to Reformation Order (1998) is relatively smooth, followed by the violence-free legislative election and the presidential election in 2004, 2009, and 2014. Meanwhile, the changing of socio-political leadership in the Middle East countries (the Arab Spring) are always overshadowed and followed by socio-political conflict and religious violence causing a lot of casualties. Socio-political life of the Muslim communities in Indonesia and in Malay world takes a different path from the Middle Eastern societies, and also form South Asia. Over the leadership transition in Indonesia, which is Islam as the majority, it can be run peacefully without violence and casualties. This paper will review the Indonesian Muslim intellectuals' contribution-as an integral part of Malay world-to the development of Southeast Asian Islamic thoughts and its contribution in framing moderate-progressive Muslim in Malay world in caring for diversity, inclusion, openness, peace and harmony in the current global world.
\end{abstract}

Keywords: Islamic studies, Islamic thought, Malay world.

\section{Introduction}

Discussing Islamic political thoughts in Southeast Asia, especially in Indonesia, to my knowledge, has inevitably involve contexts such as 
cultural context, social context and even the context of the development of existing human experience and consciousness. Islamic political thoughts worldwide have always related to the social conditions and grow along with the development of social-scientific worldview. Islamic thought cannot be separated away from the context of space and time (al-zamkany) and the level of development of consciousness of humanity and the progress of science (nazariyyat alma'rifah) where it grows, develops and conceived and studied. ${ }^{1}$ The Islamic political thought growing and developing in the Middle East regions will be very different from its design patterns of epistemology, face and socio-cultural display as it grows and develops in the regions of Central Asia, South Asia, and Southeast Asia. Similarly when it now began to sprout and it will grow and develop in the western region such as Europe, America, Australia and so on, which in time will become an integral part of the intellectual discourse of Muslims wherever they are. ${ }^{2}$

How do we understand a variety of areas and regions of the world are very different according to the context of each of these? It is not easy to understand this intricate and complexity if we just use the old style approach, textual approach. The path taken is no other way, except we had to venture out of the textual theology to a contextual theology. In the case of contextual theology, it requires inputs and contributions from other scientific perspectives such as social sciences and humanities. ${ }^{3}$ For instance, a historian Marshall GS Hodgson in his

1 Muhammad Shahrur, Naḥw Ushülin Jadidah li al-Fiqh al-Islamiy: Fiqh al-Mar'ah (alWasiyyah-al-Irth-al-Qawwämah al-Ta'addudiyyah al-Libās) (Damascus, Syria: al-Ahali li alTibāah wa al-Nasyr wa al-Tauzi, 2000), p. 116.

2 I refer to the new realities of the Islamic world map in the second half of the 20th century, where Muslim immigrants continue to grow and evolve in Western countries. Among them are the intellectuals and scholars who wrote the books of Islamic religious literature on academic level with a new perspective, which is different from the perspective of Islamic thought used before. Books such as Omit Safi's (ed.), Progressive Muslims, or Abdullah Saeed's Interpreting the Qur'an: Towards a Contemporary Approach, for examples, at present and in the future will color dynamics of Islamic thought wherever. See also Richard C. Martin, "Fazlur Rahman's Contribution to Religious Studies: A Historian of Religion's Appraisal," Early H. Waugh and Frederick M. Denny (eds), The Shaping of an American Islamic Discourse: A Memorial to Fazlur Rabman (Atlanta, Georgia: Scholars Press, 1998), pp. 243-259.

3 This has been a long need felt by Indonesian Muslims. The establishment of the State Islamic Institute (IAIN), 1951 is an important part of the history of the development of Islamic religious education in the country. This is reinforced by the institutional and 
The Venture of Islam ${ }^{4}$ sees that Islamic civilization will be able to help explain how the Islamic civilization developed in the long sweep of history in the region. At the same time, it can also be used to read how a community effort, scholars and Muslim intellectuals develop Islamic thoughts in general and Indonesian Islamic political thought in particular and Malay world in general.

Marshall Hodgson distinguishes three forms of the phenomenon of the spread and development of Islamic civilization, namely: firstly, the phenomenon of Islam as a doctrine (Islamic), secondly, the phenomenon when the doctrine was entered, pervasive, struggled in the intense and complex encounters with local culture (Islamicate) and manifest in a particular social and historical context. And thirdly, when Islam becomes a phenomenon of "Islamic world" that is political in governmental institutions (Islamdom) departing from the concept of "dar al-Islam", as what has happened in the Christian world, called Christendom, where the legal provisions applied as al-Qur'an or gospel do. So, there are three important keywords to understand the history and civilization of Islam, those are Islamics, Islamicate and Islamdom. ${ }^{5}$

One of the principal characteristics of Indonesian Islamic thought is developed by the Indonesia founding parents ${ }^{6}$ and forwarded by Muslim scholars and intellectuals show the necessary involvement of social and cultural context to comprehend the realities and dynamics of Islamic theology and Islamic political thought in the country. ${ }^{7}$ It is not

scientific transformation of IAIN to the State Islamic University (UIN) in the 2000s. Now we can find faculties at IAIN and UIN called the Faculty of Islamic Theology and Humanities, Faculty of Adab and Humanities, Da'wa and Communication and so on.

${ }_{4}$ Marshall GS. Hodgson, The Venture of Islam: Conscience and History in a World Civilization, Vol. 1 (Chicago: The University of Chicago Press, 1974).

5 Ibid., pp. 56-62.

"I prefer to use the word "parents" instead of "fathers" due to the fact that women also actively participated in the struggle for the independence of Indonesia from Dutch colonialization. See Yudi Latif, "Pancasila: Idealitas dan Realitas," an inaugural speech as a new member of Indonesian Academy of Sciences (AIPI), Cultural Commission, University of Pancasila, Jakarta (24 Juli 2017), p. 6.

7 The context of the existence of Christian communities in the eastern part of Indonesia, for examples, inspired the founding parents of Indonesia to delete the phrase 'obligations to run Islamic law for the Muslims' from the preamble of Indonesian Constitution. This document is well known as the Jakarta Charter. This nearly same issue can be found also in Malaysia related to the legitimacy for nonMuslim to be a member of national political party (the Alliance of UMNO and MCA) 
limited to classical Islamic political thought, or popularly called now Turath (here, I understand it in a very limited sense, namely Textual Islam) alone. It has been able to penetrate and see the reality of the history of Islamic civilization in the concrete socio-cultural-political reality surrounding the text (al-nas wa ma haulahu), both the classical era, middle and modern. Indonesian Muslim intellectuals refer to it as a process of indigenization and also some call modernity (al-Hadathah), to the context of people's lives now, when a Muslim man agreed to establish a nation-state. It is the socio-intellectual struggles that are then transferred into the mind of the spirit of Indonesian Muslims (Islam in Context). To borrow Tariq Ramadlan's phrase, how Islam (in the text) proceeds, manifests, dialectic, met and blended deeply with the local culture and then morphed, transformed into Indonesian Muslims, not the Islam that is distant from both local and cultural dynamics of social, economic, the culture and mainly culturally (Islam in Indonesia), mainly not Islam which is doubtful and hesitant to blend with the local culture. To some extent this deep and serious intellectual struggle can be traced in Nurcholish Madjid's work Islam: Doktrin dan Peradaban and Abdurrahman Wahid's work Pribumisasi Islam. ${ }^{8}$

Since the beginning of the emergence of Indonesian Muslim intellectuals after the independence, represented by Nurcholish Madjid, the discourse of development stage in Indonesian Islamic thought, Ibn Taymiyyah's ideas of Kalam and 'aqïdah, al-Ghazali's and Ibn Araby's tasawwnf, Ibn Rusdh's fiqh, and other classical Muslim thinkers, have been illustrated clearly in his Khazanab Intelektual Islam. ${ }^{9}$ Everything was then mated with a dialogue and thoughts of historians, such as Marshall Hodgson, a sociologist of religion, such as Robert N. Bellah and such others, are then fused and blended in the thinking and

and his possibility to be promoted as a candidate of national leader in Malaysia. See Yuki Shiozaki, "From Mecca to Cairo: Changing Influences on Fatwas in Southeast Asia," Masooda Bano and Keiko Sakurai (eds), Shaping Global Islamic Discourses: The Role of al-Ažbar, al-Medina and al-Mustafa (London: Edinburg University Press in association with The Aga Khan University, (International) in the United Kingdom, Institute for the Study of Muslim Civilizations, 2015), pp. 181-2.

${ }^{8}$ Nurcholish Madjid, Islam: Doktrin dan Peradaban. Sebuah Telaab Kritis tentang Masalab Keimanan, Kemanusiaan dan Kemoderenan (Jakarta: Yayasan Wakaf Paramadina, 1992). Even in 1995, his other book, explicitly called "history". The book is Islam Agama Peradaban: Membangun Makna dan Relevansi Doktrin Islam dalam Sejarah (Jakarta: Paramadina, 1995).

${ }_{9}^{9}$ Nurcholish Madjid, Khazanab Intelektual Islam (Jakarta: Bulan Bintang, 1984). 
analytical framework intact. In the public speaking, in seminars, lectures and speeches, the marriage and the interweaving of Muslim intellectual treasures of classical (al-Turath) and modern social sciences (al-Hadathab) always appear there. That is one of the characteristics of many other traits, which distinguish the Indonesian local Islamic theological and political thought from patterns of local Islamic theological and political thought in other areas of the Muslim world.

\section{Plurality, inclusiveness and al-hanifah al-samha'10}

Local expressions of Indonesian Islamic political thought have been blended and dangled in terms of plurality, tolerance, inclusiveness, al-hanifah al-samba' and dialogue. It was like a lightning striking in broad daylight when Nurcholish Madjid, as a one of the representatives of Indonesian Muslim intellectual in the 80 and 90s, with a loud and firm talked about Islamic thought patterned in alhanifah al-samba' (tolerance, solidarity, and openness), plurality (alta'addudiyyah) and inclusiveness (al-tadhamuniyyah). He snatched in broad daylight because of the general Islamic thought that developed in Islamic boarding schools, Islamic colleges, especially in public colleges, not to mention the various types of majlis taklims (gatherings for religious teaching for Muslim) and halaqah-halaqah Tarbiyah (forums for religious trainings) and also developed in various Islamic organizations in the country are not such types. Generally, the patterns are still exclusive, closed, sectarianism, primordial, parochialism, madhbabiyyah, bizbiyyah, ta'ifiyyah. The situation and socio-political psychology in the country at that time-even to a certain extent until now and again there are still ones who want any sort of Islamdom (political Islam, caliphate, al-kbiläfah al-Islamiyyah, al-daulah al-Islamiyyah) because the majority of Indonesia's population is Muslim (87\%). It is then natural, if there is some interest groups who want the establishment of a kind of religious state or an Islamic state here, but unfortunately with the exclusion of a deal to pull off the founding parents' consensus and agreement, the founder of the republic, the nation-state, Indonesia.

The dictum Nurcholish Madjid proclaimed was "Islam, Yes, Islamic party, No?" that is, Islam which is patterned al-hanifah al-samba',

\footnotetext{
10 al-Hanifa al-samba is defined as "the true and tolerant religion". See Hans Wehr, $A$ Dictionary of Modern Written Arabic (Arabic-English) (Wiesbaden, Otto Harrassowittz, 1976), p. 500. It is also commonly called ḥanifiyyatu al-sambah.
} 
tolerant, open, airy, and which can receive and cooperate with people and other groups in building the welfare of the citizens of the nationstate of Indonesia together is Yes. Not Islam which is rigidly trapped in exclusive pattern, sectarianism, primordial, madhbabiyyah, bizbiyyah and taifiyyah, which is only concerned with the internal interests of their own group, but cannot accept, let alone cooperate with people, organizations and groups, religions, tribes, other races. Although it was felt bitterly at that time, but sweetness can be perceived at the present time, especially when we all, as a big family and the citizens of the Indonesian nation today in comparison with the looking, observing and following the development of socio-political-religious conflicts in the Middle East (Arab Spring).

Basically, local expression of Southeast Asian Islam and Malay world in particular is moderate. The Southeast Asian's Islamic cultures are to be polite and friendly to the dissenting interpretation and understanding of different religious perspective. Pancasila as the ideological foundation of the modern era and the nation, which is extracted from the roots of the culture of Indonesia, also reflects the Weltanschaunng of Indonesian society in general. The 5 pillars of Pancasila, namely, Belief in One God, Just and Civilized Humanity, the Unity of Indonesia, the Democracy Guided by the Consultative Representative Policy Lessons, and Social Justice for all Indonesian people, on one hand, is the culmination of national compromise, meeting point agreement of the noble values (kalimatun sawa'; common platform) obtained from the various local cultures, cultures that spread across the nation (Islam in the context of culture), while on the other hand it is a meeting point and central points of Islamic teachings contained in the holy book al-Qur'an and the books of figh siyasab/classical political (Islam in Text). With a philosophical foundation solid-state constitutional as it is, the Indonesian Muslim community has been completed with itself and has also completed his struggle with the idea of the modern nation and state. It is the completion that constitutes the core of the Indonesian Muslim community's identity, which represents the largest Muslim communities in Southeast Asia. It is also the capital that will be used for facing and into the common life of the Asian economic community, AFTA as well as the member of the world citizenship.

The failure to care for and strengthen the joints of the life and governance of the modern era of the nation-state in most countries in 
the Middle East and other parts of the Muslim world is caused by the strength of ideology, the harsh doctrine, or a rigid socio-political understanding of Islamic principles, known as al-walla' wa al-barra ${ }^{-11}$ (only loyal to the person, group, organization, sect, party of the same religion, religious denomination and disloyal or reject any leader who does not come from their own religious groups, school, organization or sects). This doctrine is quite powerful, instilled by social and political groups fighting each other for socio-political power in the Middle East region. Theological-political strives and disputes between Sunnis and Shi'i are not finished, even deepened, in the various regions in the Middle East, and tend to venture into other areas, such as in a South Asia is rooted in the doctrine of figh al-siyasah (religious political doctrine) pattern in the such classic text. Ideology takfir or takfiriyyah originated from the Middle Eastern areas and spread out in society and in social media networks, i.e. considering other group of different religious understanding and interpretations as infidel, apostle and unbelievers are also based on the doctrine of al-walla', wa al-barra', (loyalty and disavowal). ${ }^{12}$

Ideology and Islamic socio-political practices declared by the founders of the Islamic State of Iraq and Syrian (ISIS), who declared a unilaterally khiläfah or al-Daulah al-Islamiyyah (Islamic State) is an antidote or antithesis of a democratic system of republic and constitutional government they consider failed ${ }^{13}$ in Iraq and Syria. The practice of Islamic caliphate (kbiläfah Islamiyyah) doctrine adopted by ISIS is really based on doctrine of al-wallà wa al-barrä, (loyalty and disavowal). Even the doctrine of loyalty and disavowal is not only limited to the selection of future leaders, but also extends to the areas of history and culture. The destruction of places of worship belonging to other religions, the destruction of cultural sites and religions, such as

\footnotetext{
${ }^{11}$ Roel Meijer, “Introduction,” in Roel Meijer (ed.), Global Salafism: Islam's New Religious Movement (London: Hurst \& Company, 2009), pp. 9-13.

${ }^{12}$ For further reading, Joas Wagemakers, "TheTransformation of a Radical Concept: al-wala, wa al-barra', in the Ideology of Abu Muhammad al-Maqdisi," in Meijer, Global Salafism, pp. 81-106.

${ }^{13}$ It is not easy to explain how the geopolitics of countries in the Middle East. Ibrahim M. Abu Rabi', a Palestinian, who lived and taught in Western universities, wrote the foreword of the book he edited, which is enough to explain helping with the hassle. See Ibrahim M. Abu-Rabi' (ed.), The Contemporary Arab Reader on Political Islam (London and New York: Pluto Press, 2010).
} 
temples, statues and other historic objects considered as a symbol of shirk, and contrary to the subjective understanding of 'Aqidah and Shariah of Islam they understand. ${ }^{14}$ The climax of this uneasy and difficult position is a clot and fertility of sectarianism (madhbabiyyah), parochialism (bizbiyyah), primordial (ta'ifiyyah) in the Muslim community that weaken the joints of social life-social and socio-political life of the nation.

Really, this type of religious political doctrine based on a classic text is in an extreme opposite with the ultimate value of studying the social sciences promulgated from the seventeenth century to nowadays. According to Gudmund Hernes, a President of International Social Science Council, Social Science has a brand new conception and its fundamental values in managing a state in a pluralistic society. I quote:

"To a great extent, the social sciences come with new ideas about religion, reason, humanity and society were merged into a fairly coherent worldview that stressed human rights, individualism and constitutionalism. Studies of alien societies were used as a contrast when analysing a country's institution and customs. A range of new, fundamental conceptions was articulated, for example: about the autonomy of the individual and inviolable rights; about individual freedom and the sovereignty of the people; about the tripartition of the state power and the independence of the state from religious supremacy; about the unfairness of inherited privileged; about the principles for organizing a market economy". 15

Furthermore, Hernes clarifies that the emergence of social sciences is equivalent with the rise Modernity in which the recognition that a plurality of opinions and an open, critical debate were necessary to gain new insights and for citizens to forge their own history. Education for all, including women, was articulated as a political goal. A free press

\footnotetext{
${ }^{14}$ A description on the relationship between religion, politics and ideology, particularly with regard to the relationship and lack of continuity between heresy and shirk understanding and sensitivity and cultural history can be read in Mirza Tirta Kusuma, (ed.), Ketika Makkah Menjadi Seperti Las Vegas: Agama, Politik dan Ideologi (Jakarta: Gramedia Pustaka Utama, 2014), pp. 1-69.

15 Gudmund Hernes, "Preface," World Social Science Report, 2010: Knowledge Divides (Paris: United Nations Educational, Scientific and Cultural Organization and International Social Science Council, 2010), p. vii.
} 
and the dissemination of knowledge were regarded as a means for enlightenment and personal development. Power could only be legitimate if it promoted the welfare of the people. Even today, many of these issues remain contentious.

Here is a crucial point confronted by Muslim society elsewhere in the world. Here is the shortcomings and weaknesses of Islamic thought in the Middle East in particular and in the Muslim countries in general, which is suspected by Ibrahim M. Abu Rabi' as Islamic thought in general and Ulum al-Din in particular which does not recognize and is lack of touch of social sciences and the valuable input of critical-philosophical-academic thinking commonly studied in the contemporary social sciences and humanities. I quote the view of Ibrahim M. Abu Rabi' as follows:

"The core of the field revolves around the Shari'ah and Fiqh studies that have been, very often, emptied of any critical or political content, or relevance to the present situation. A clear-cut distinction has been made between the "Theological" and the 'political' or the 'Theological' and the 'social', with the former being Understood as rites, symbols, and historical text only. Furthermore, the perspective of the social sciences or critical philosophy is regrettably absent. The modern field of Shariah studies in the Muslim world has remained closed off to the most advanced human contributions in critical philosophy and social sciences". ${ }^{16}$

Indonesian Muslim intellectuals especially who dedicates their academic works in the State Islamic Higher Education (PTKIN) take another path. From 1980 onward, the idea of social sciences are initially introduced and blendered with Uhim al-Din (Islamic knowledge) and finally developed in 2000s as Islamic Studies (Dirasat Islamiyyah). ${ }^{17}$ Even, in some circles in the State Islamic University

16 Ibrahim M. Abu Rabi', “A Post-September 11 Critical Assessment of Modern Islamic History," in Ian Markham and Ibrahim M. Abu Rabi', 11 September: Religious Perspectives on the Causes and Consequences (Oxford: Oneworld Publications, 2002), pp. 3334. Even in page 36 it is mentioned that "the discipline of the sociology of religion is looked upon as a heretic, or innovation, that does not convey the real essence of Islam".

${ }^{17}$ M. Amin Abdullah, "Mempertautkan 'Ulūm al-Dīn, al-Fikr al-Islāmiy dan Dirāsat alIslämiyyah: Pendidikan Karakter Sosial-keagamaan melalui Pendekatan Multidisiplin dan Transdisiplin," Direktorat Pembelajaran, Direktorat Jenderal Pembelajaran dan 
(UIN), they already introduced Religious Studies and a Comparative Study of Religion. The dialogue, debate and encounter between these three clusters of disciplines are clearly seen in their scholarly works. Great ideas on Islamic social and political thought written by the Indonesian Muslim scholars in their books are then seeded, captured and disseminated either directly or indirectly by networks of Islamic colleges in the country. There are other networks participating in caring for and developing new ideas and inclusiveness, plurality, alhanifah al-samba', tolerance and dialogue, but those who applied systematically, academically and in an institutionally structured is through a network of Islamic Higher Education in the country. The fundamental concepts are included in books and other written works, through bulletins, magazines, journals, hard copy or electronic, which in turn are then included into the core curriculum and syllabus of teaching and giving religious lectures in college for lecturers. Furthermore, it drives a spirit of research of Islamic thought and Muslim society in the country.

Later, around the $90 \mathrm{~s}$, the idea even grows more along with the establishment of study centres inside and outside the religious colleges, training and trainings carried out by social activists through youth organizations, womanhood, and the general and religious court, and health organized by civil society. ${ }^{18}$ The themes developed into broader areas, such as intercultural dialogue, inter-religious dialogue, dialogue of cultures and religions, religion and gender, religion and human rights, religion and disaster mitigation, religion and the environment, religion and demography, religion and multiculturalism, religion and science, and so on. What are effects to the life of the nation? Indeed, it turns out that Islamic understanding and thinking of this contextual model has immense influence in the long, continuous, and relentless

Kemahasiswaan, Kementrian Riset, Teknologi, dan Pendidikan Tinggi, Memandang Revolusi Industri \& Dialog Pendidikan Karakter di Perguruan Tinggi, Jakarta: Direktorat Pembelajaran, Direktorat Jenderal Pembelajaran dan Kemahasiswaan, Kementrian Riset, Teknologi, dan Pendidikan Tinggi, 2017), pp. 131-156.

${ }^{18}$ Listia, Purwono Nugroho Adhi, and Sartana, Pendidikan Interreligius: Gagasan Dasar dan Modul Pelaksanaan, Buku Suplemen Pendidikan Agama untuk SMA (Surakarta: CDCC, Religions for Peace, KAICIID Dialog Center, 2016); Suhadi, Linda Bustan, Listia, Purwono Nugroho Adhi, Pendidikan Interreligius: Gagasan Dasar dan Modul Pelaksanaan, Buku Suplemen Pendidikan Agama untuk Perguruan Tinggi (Surakarta: CDCC, Religions for Peace, KAICIID Dialog Centre, 2016); Eddy Aqdhiwijaya et.al., Pendidiken Interreligius: Non-Formal (Surakarta: CDCC, 2016). 
process of nation and character building in the Indonesian Muslim community.

The influence and impact can only be felt when the public and international observers compare the life of nation in Indonesian Muslims with a life of the nation in the various regions of the world, especially in a part of the Middle East region. Without reducing the role of other universities, it is worth noting that if there is no Islamic higher educational institutions (PTA; PTKIN) in the country, which has now 57 Islamic Religious Higher Education, which consists of 17 State Islamic University (UIN), 26 State Islamic Institute (IAIN) and 14 State Islamic Colleges (STAIN), not to mention more than 569 private universities, institutes ad colleges (PTAIS; PTKIS), we cannot imagine what will happen to this nation and how this nation, from Sabang (Western part of Indonesia) to Merauke (Eastern part of Indonesia) can maintain social-political-religious stability and still stand on a rigorous bases at the present time ${ }^{19}$.

In fact, in many Muslim-majority countries in the world, no or not all can accept the governance model of the modern state wholeheartedly with a system of nation-state as we have done in Indonesia, namely the governance of the nation-state, which is based on the constitution, democracy, plurality, equity and protection of human rights. If they had accepted, they could not solved yet the problem of Sunni and Shici in their own country. One of the important points in the Constitution in the nation-state is a democracy, namely the implementation of honest and fair elections in to elect the people's representatives through legislative elections and elect a presidential candidate through the presidential election. Not most populous Muslim nation, to take an example of Pakistan and Egypt, did well in preserving the Constitution of holding elections and presidential elections. In carrying out elections, in Pakistan, for example, there have been almost some riots with their casualties. The victims can be from among the participants/contestants and presidential elections or even among the candidates of leaders of the state (prime minister).

After 30 years of unconstitutional presidency of President Hosni Mubarak in Egypt, there was a movement of people who wanted to

${ }^{19}$ For the dynamic of the Islamic Higher Education, see Ronald A. Lukens-Bull, Islamic Higher Education in Indonesia: Continuity and Conflict (New York: Palgrave Macmillan, 2003). See also Carool Kersten, Islam in Indonesia: The Contest for Society, Ideas and V alues (London: C. Hurst \& Co Publishers, 2015). 
drop him from his position. Something like what happened in Indonesia in 1998. Looking for his substitution was not an easy thing. There were some victims. Once, after the election of a new president, it turned out that some people and supporters of the elected president also could not understand and run the Constitution well happened in Afghanistan, Syria, Iraq, and also in Libya. Only Tunisia had a good chance to resolve their internal problem today. Again, the situation was not conducive. Arab Spring has not successfully completed or resolved their constitutional problems. The UN noted that the political crisis in Syria since 2011 took the lives of no less than 500,000 people. The unsuccessful managing the nation-state is sharpened and exacerbated by the declaration of the Islamic State of Iraq and Syria (ISIS) in 2013.

\section{Indonesian Muslims' Intellectual Contribution}

By such comparison, we are all then reminded by what the scholars, intellectuals and thinkers of Indonesian Muslim intellectuals and others called about the importance of being tolerant, inclusive, and non-discriminatory, non-violence in facing various disagreement, belief, religion, sect, ethnicity, race, gender, class and so on. The call was echoed continually, tirelessly, and led to expletive risk from other community, so it can lead the Indonesian nation to run a 5-year state constitution, namely selecting candidate of state leader/president very well, successfully, and with no casualties. Although the process of attracting voters, among a part of campaigners, preachers, sympathizers and volunteers often use religious issues, beliefs, and race pretty hard-fierce (black campaign), but at the grassroots level there is no significant friction and dispute. Without ignoring the role of other religious communities, the role of Muslims who constitute the majority of Indonesia's population became the backbone of the success of understanding the idea of "nation-state" and "democracy" as stipulated in the constitution of the Republic of Indonesia. They are not easily boxed, mangled and torn apart by the issue of difference of religion, belief, race, ethnicity and class despite the temptation, incitement, solicitation, appeal to a political sectarianism and primordial sentiments and sometimes by intimidation and the threat at any occasion.

There are at least three important things that the clergy, scholars and Muslim intellectuals in Indonesia have conditioned in various layers noteworthy as their legacy in an attempt to enforce the Constitution in the modern nation-state and the continuity of life care 
for democracy, and the state policy of non-discrimination in the country. That is a legacy, that will contribute to facilitate the inclusion of Indonesia in the Asian and world community without major obstacles, distributed by many people, religious universities, nongovernmental organizations, and discussion of social activists and civil society in general.

\section{The Convergence of Religious Faith (Distinctive Values) and the Benefit of the Nation-state (Shared Values)}

Indonesian Muslims, as well as other religious communities ${ }^{20}$, to a certain degree have been able to independently consider, articulate, and fabricate critically and the point of convergence between faith, religious beliefs and rituals of Islam (distinctive values) on the one hand and welfare and common interests (shared values), for the achievement of national unity-community-humanity and world peace in the format of a nation-state on the other. Not less than 133574277 valid voters go into the voting booth. They are with full sovereignty vote according to their choice. They are not easily provoked by negative issues that exploit racial sentiments, tribal, ethnic and religious issues. Religious life, nation and state in this country will be always tested its durability once every five years of parliamentary and presidential elections, not to ignore dozens of elections, of governors, regents, the elections in the entire country.

Obviously, the Indonesian Muslim community, on this point, has a qualitative advantage and comparative advantage compared with other nations with a Muslim majority in the world. Other nations are not, or have not been able to do positive-constructive dialogue between religious faith and the state of the nation as practiced and experienced by the people of Indonesia. Other nations in the world that still puts one above the others even smashed it. Indonesian nations can articulate and use the autonomous-rational choice in determining the nation's future leaders, without being influenced by black campaign that precedes and accompanies it before entering the voting booth.

20 Other Religious followers are not passive either in anticipating any religious and national issues. One of the advocates of interfaith dialogue in a Christian environment that is still active is Interfidei (Inter Faith Dialogue) in Yogyakarta. How difficult they were in facing Christian plurality as reflected in Th. Sumartana's 1971 thesis to be published by Interfidei by the end of 2014, entitled Soal-soal Teologis dalam Pertemuan Antar Agama (Theological Problems in Interfaith Meeting). 
The experience of building harmonious relationships and peace in this country will be a strong social and cultural capital base to build harmonious relationships and peace in the international environment and the Asian economic community.

The quality level of civility and dignity of a nation and the state is largely determined on how the types of relation between "faith in (any) religion" and "diversity of social life within the nation-state" were. Encounter and dialogue between the two that fail to reach the culminating point of convergence, not the truth and the common good to be obtained, but on the contrary, deficit of truth and socioeconomic-political misery and woes.

\section{Plurality, Democracy, Inclusiveness as an Integral Part of the New Mașlahah (Common Good) Theory.}

Indonesia is an archipelagic country in the forms of archipelagos. A maritim, especially archipelagic mentality is totally different from a continental mentality. ${ }^{21}$ Building a great and strong wall is a typicality of continental mentality when the people want to solve their social, political and ideological differences, disputes and conflicts. The people in the archipelagos do not have a such experience to build a great wall like Berlin wall in the time of cold war between capitalism in the West and socialism in the East. There are not less than 15,000 islands in this country. All the time, before Indonesia gained its independence and became a nation-state in 1945, the people of the archipelago have been in diversity. Plurality and diversity is woven of knit of social community archipelago since a long time ago, since the imperial era, some centuries ago and the former Dutch colonial era. Because of the complexity of diversity/plurality of the archipelago then the founding parents of the Republic of Indonesia chose the state governance system in the form of the nation-state (nation states), not in the form of Islamic theocracy, although according to the count of population statistics Muslim communities occupy a high percentage, more than $87 \%$. In addition to race, ethnicity, class, language, religion and beliefs of diverse, diversity if it also can be viewed in terms of geography, territory and even in terms of time (East, Central, and West of Indonesia).

${ }^{21}$ Primadi Tabrani, Belajar dari Sejarah dan Lingkungan (Bandung: Penerbit ITB, 2011). 
The Indonesian human collective memory of the diversity and plurality in various aspects of life is very strongly attached and deeply embedded in the sub-consciousness of religious Indonesian society, whatever their religions are. Unconscious collective memory of the diversity and plurality becomes extraordinary power enormity to be tolerant, inclusive, open-minded, open, and so easily lead to resolve complex problems and complex socio-religious and socio-nationality. Nurcholish Madjid, calls it as fitrah majbulah, the nature which is firmly rooted in man, namely conscience. The power of the subconscious is fresh in his conscience about varieties, diversity and inclusiveness of this, when necessary, may transform into a positive spiritual energy, which can reduce the seeds of discord that sometimes come to the surface.

The socio-cultural capital transforming into a diversity of political morality is a matter of basic social life of the Indonesian nation, which at the needed time will provide immunity strength of the pull of group egoism (ta'assubiyyah; madhhabiyyah, hizbiyyah, ta'ifiyyah). The strength and cultural and social capital in its journey can be combined with the understanding and development of socio-political thinking of Indonesia Islam having typical characteristics in interpreting the verses of the Koran, 18 verses in the surab 49 of al Hujurat, especially verse 13:

"O mankind, We created you from a single (pair) of a male and female and made you into nations and tribes that ye may know each other. (Not that ye may despise (each other). Verily, the most honourable of you in the sight of God is (he who is) the most righteous of you. And God has full knowledge and is well acquainted (with all things). (The Holy Qur'an: meanings translated by Abdullah Yusuf Ali, Beirut Lebanon: Dar al Arabia, n.d., p.1407)

The understanding of the doctrine of Islamic Tawhid through socio-religious commentary having patterns of al-Hanifah al-samba' (tolerant), pluralist and inclusive is an integrated part of the development maslahah (common good) theory in the study of contemporary usūl al-figh. ${ }^{22}$ This Maslahah theory development in usul al-figh got the right momentum to be applied and implemented in the

22 Jasser Auda, Maqāsid al-Shari 'ah as Philosophy of Islamic Law: A Systems Approach (London and Washington: The International Institute of Islamic Thought, 2008), pp. 5-9; and pp. 21-25. 
country, in the Pancasila-based nation-state format. This is what might be called by Marshall Hodgson as the Islamicate which is unique and highly complex in the archipelago, which is very different from the mode of development of the other Islamic local communities in the international level, which is then transformed into a republic of Indonesia (1945), long after the approval of the Youth Pledge, in 1928. Interpretation and understanding Islam, which has conservative and fundamentalist pattern ${ }^{23}$ (not sensitive to the profound and fundamental historical and cultural development and the development of human life in accordance with the pace of progressive ideas), primordial and sectarianism, past-oriented then, not creative, no sympathy and strong support from the large public in Indonesia.

This problem is not completely correct, because Indonesia has very broad territorial region, also cannot be simply separated from religious conservatism and fundamentalism having sources from the country of overseas. Attraction and temptation are not only from abroad, as in the country there is a lot of things that can be a potential source for the development of life-fundamentalist religious interpretations, especially when the government cannot perform well in the fulfilment of fundamental rights to all its citizens (Rights), cannot deliver a genuine recognition for the existence of each individual and diverse groups (Recognitions) and unable to do justice in economic distribution in the country (Redistributions).

\section{Social Cohesion as the Social and Cultural Capital of Indonesia}

It has been very long time since sociologists of religion found one social function of religion in society is to maintain cohesion and social unity. When the theory was developed, pioneered by Emile Durkheim,

\footnotetext{
${ }^{23}$ The term "fundamentalism" to some readers connotes a good and positive meaning. Accepting fundamentalist using a literal translation of the term into Arabic by saying usüliyyun is a good thing. In connection with religion, this term is suggestive of "the principle of religion" (usul al-din), a well known title for many medieval handbooks of Islamic theology (Kalam) as a positive disposition that needed to be distinguished from fanatism and extremism. Only the latter were associated with negative connotations while fundamentalism developed a much more positive image than previously understood, when it was exclusively associated with antimodern tendencies. See Peter Antes, "New Approaches to the Study of the New Fundamentalism," Peter Antes, Armin W. Geertz, and Randi R. Warne (eds), New Approaches to the Study of Religion, Volume 1, Regional, Critical and Historical Approaches (Berlin, New York: Walter de Gruyter, 2004), p. 440.
} 
it might that the first imagination of social cohesion or unity is only limited in the scope of the internal circle of a particular religious community itself. In the Indonesian Muslim community, all the time and more after the independence of the Republic of Indonesia, the theory of social cohesion is not only interpreted as unity, harmony, peace, solidity and solidarity in the internal environment a particular religion. The meaning has been expanded into the unity of Indonesia. Here, once again, for the case of Indonesia, faith in religion has dialecticism and has been fused with the idea of nationality and universal humanity. That is to say, religious solidarity often having religious-sectarian character of primordial (ta'ifiyyah; bizbiyyab) has changed, and morphed into national solidarity-humanity (al-wataniyyah; al-insaniyyab). Again, this is a unique case in the religious experience and local Indonesian nationality. However, it is difficult to achieve, if it was not previously covered only by the social and cultural capital that has been powerfully imprinted, neatly interwoven, and deeply-internalized in the structure and nature of Indonesian society's subconscious thought, any ethnicity, race, ethnicity, language and religion he follows.

It was the meetings and encounters between the great variety of ethnicity, races, language, religion and belief in the mother land that has been the strength of the subconscious and animates the daily life of Indonesian society. Again, it was the positive-constructive meetings and counters that deliver great meritorious Indonesian people to be able to get out of the very complex crisis before, in the midst of and after the presidential election recently. At this point, we are reminded to Nurcholish Madjid's dictum: "Islam Yes, Islamic Party, No".

It seems that Indonesian grassroots social order is something like what the Qur'an has described in surah Al 'Imran, verse 159 as follows:

"It is part of the Mercy of Allah that thou dost deal gently with them. Wert thou serve or harsh-hearted, they would have broken away from about thee: so pass over (Their faults), and ask for God's forgiveness for them; and consult them in affairs (of moment). The when thou hast taken a decision, put thy trust in God. (The Holy Qur'an: meanings translated by Abdullah Yusuf Ali, Beirut Lebanon: Dar al Arabia, n.d., p.164)

\section{Conclusion}

The socio-political thinking of Indonesian Islam was initiated by the Indonesian Muslim intellectuals is an unfinished project. 
Nevertheless, it has a huge impact on the Malay world. There are still a lot of hurdles that continuously block at any time in the course of a long life of the nation in the Republic of Indonesia and in the Malay world in general. If mapped, areas of thought and praxis in the field fall into three layers, namely, first, the level of discourse (al-khitäb); second, normative-regulative level, and the third is an applicativeimplementation level in real people's lives on the ground, then the contribution of moderate and progressive Muslim Indonesia already succeeded in raising the issue of the level of plurality, inclusiveness and tolerance (al-hanifah al-samba) in religious life and nation-state at the level of public discourse. This was an outstanding and significant intellectual contribution because there are not many nations in the Muslim majority world who can receive such discourse. We know many books were banned to enter into a particular country-let alone get read-because they address the question of plurality or alta'addudiyyah.

At the level of normative-regulative there are still many stumbling stones in the wider community, in a variety of ministries, both religious ministry of religious affairs, ministry of home affairs and the ministry of law and human rights. There are more on the application and implementation levels such as in the leadership of religious organizations, legislative candidates, governors, regent, village heads and so on. The dynamics in each situation may vary. Some are successful and some are not, depending on the style and depth of one's religious literacy, the mastery of the three initial thoughts.

Can these all be referred to as the paradox of plurality? I don't think so. Since the completion of the three-layer problems is not a kind of once-for-all religious and national technical-technological work, but this is a humanistic work that requires more detailed and sustainable work, and must run continuously in improvement. There are still a lot of household works left by Indonesian Muslim thinkers. And this domain is much more difficult and complex. Generation of Muslim intellectuals' in the era of Asian and World Economic Community should continue their earlier Muslim intellectuals' struggles in developing the socio-political thought of Indonesian Islam.

We'd better looking forward to the nation's journey with optimism. Indonesian Muslims have strong socio-cultural capital that has been able to bring into the dignified and civilized life of the nation-state. There are many problems to face by this nation; free trade Asian 
society, a greater inter-faith interaction in a more increasingly cosmopolite world, with a high rate of social violence, hatred and exclusively religious understanding, social violence and religious differences, school, stream, the subjective interpretation of religious text, religious conservatism and fundamentalism, hatred and violence on religious grounds (takfir -takfiriyyah ideology) improving the quality of education, especially the equal access for women, the development and improving the welfare of lower income/grass-root community, social reconciliation, politics and culture, internal religious harmony of Muslims, religious harmony, social medias which are literate on issues of religious plurality, eradication and prevention of corruption and many others.

There are still open windows to welcome new hope for prosperity and the unity of Indonesia, especially after the integrity of Asian economic community. The elites and leaders are strongly to start, as commonly referred to by the media, social reconciliation. Indonesian people at the grassroots level seem to be more mature than the elites in understanding, analyse and resolving cultural differences. So it is the elites, with a variety of conflicted interests, who need to prioritize the promotion of ideological-political relation that encourages Indonesians to maintain the unity of the people, concentrating their mental and spiritual energies to the development of the social welfare.]

\section{References}

\section{Books and Articles}

Abu-Rabi', Ibrahim M. The Contemporary Arab Reader on Political Islam. London and New York: Pluto Press, 2010.

Antes, Peter, Armin W. Geertz, and Randi R. Warne (eds), New Approaches to the Study of Religion, Volume 1, Regional, Critical and Historical Approaches. Berlin, New York: Walter de Gruyter, 2004.

Aqdhiwijaya, Eddy, et.al. Pendidikan Interreligius: Non-Formal. Surakarta: CDCC, 2016.

Auda, Jasser. Maqasid al-Shariah as Philosophy of Islamic Law: A Systems Approach. London and Washington: The International Institute of Islamic Thought, 2008.

Bano, Masooda and Keiko Sakurai (eds). Shaping Global Islamic Discourses: The Role of al-Azhar, al-Medina and al-Mustafa. London: 
Edinburg University Press in association with The Aga Khan University, (International) in the United Kingdom, Institute for the Study of Muslim Civilizations, 2015.

Direktorat Pembelajaran, Direktorat Jenderal Pembelajaran dan Kemahasiswaan, Kementrian Riset, Teknologi, dan Pendidikan Tinggi. Memandang Revolusi Industri \& Dialog Pendidikan Karakter di Perguruan Tinggi. Jakarta: Direktorat Pembelajaran, Direktorat Jenderal Pembelajaran dan Kemahasiswaan, Kementrian Riset, Teknologi, dan Pendidikan Tinggi, 2017,

Hernes, Gudmund. "Preface," World Social Science Report, 2010: Knowledge Divides. Paris: United Nations Educational, Scientific and Cultural Organization and International Social Science Council, 2010.

Hodgson, Marshall G.S. The Venture of Islam: Conscience and History in World Civilization. Chicago dan London: The University of Chicago Press, 1974.

Kersten, Carool. Islam in Indonesia: The Contests for Society, Ideas and $V$ alues. London, Palgrave Macmillan, 2015.

Kusuma, Mirza Tirta (ed.). Ketika Makkah Menjadi Seperti Las Vegas: Agama, Politik, dan Ideologi. Jakarta: Gramedia Pustaka Utama, 2014.

Listia, Purwono Nugroho Adhi, and Sartana. Pendidikan Interreligius: Gagasan Dasar dan Modul Pelaksanaan, Buku Suplemen Pendidikan Agama untuk SMA. Surakarta: CDCC, Religions for Peace, KAICIID Dialog Center, 2016.

Nurcholish Madjid, Khazanah Intelektual Islam. Jakarta: Bulan Bintang, 1984.

Islam: Doktrin dan Peradaban. Sebuah Telaab Kritis tentang Masalah Keimanan, Kemanusiaan, dan Kemoderenan. Jakarta: Paramadina, 1992.

-------. Islam: Agama Peradaban. Membangun Makna dan Relevansi Doktrin Islam Dalam Sejarah. Jakarta: Paramadina, 1995.

Markham, Ian and Ibrahim M. Abu Rabi' (eds). 11 September: Religious Perspectives on the Causes and Consequences. Oxford: Oneworld Publications, 2002. 
Meijer, Roel (ed.). Global Salafism: Islam's New Religious Movement. London: Hurst \& Company, 2009.

Saeed, Abdullah. Interpreting the Qur'an: Towards a Contemporary Approach. London and New York: Routledge, 2006.

Safi, Omid (ed.). Progressive Muslims: On Justice, Gender and Pluralism. Oxford: Oneworld Publications, 2005.

Shahrur, Muhammad. Naḥw Ushülin Jadidah li al-Fiqh al-Islamiy: Fiqh alMar'ah (al-Wasiyyab-al-Irth-al-Qawwamah al-Ta'addudiyyah al-Libäs). Damascus, Syria: al-Ahali li al-Ṭibāah wa al-Nasyr wa al-Tauzi, 2000.

Suhadi, Linda Bustan, Listia, Purwono Nugroho Adhi. Pendidikan Interreligius: Gagasan Dasar dan Modul Pelaksanaan. Surakarta: CDCC, Religions for Peace, KAICIID Dialog Centre, 2016.

Sumartana, Th. Soal-Soal Teologis dalam Pertemuan Antar Agama. Yogyakarta: Interfidei, 2015.

Tabrani, Primadi. Belajar dari Sejarah dan Lingkungan. Bandung: Penerbit ITB, 2011.

Waugh, Early $\mathrm{H}$ and Frederick M. Denny (eds). The Shaping of An American Islamic Discourse: A Memorial to Fazlur Rahman. Atlanta, Georgia: Scholars Press, 1998.

United Nations Educational, Scientific and Cultural Organization and International Social Science Council. World Social Science Report, 2010: Knowledge Divides. Paris: United Nations Educational, Scientific and Cultural Organization and International Social Science Council, 2010. 
M. Amin Abdullah

$\mathbf{3 2 8} \mid$\begin{tabular}{l|l} 
JOURNAL OF INDONESIAN ISLAM \\
VOLUME 11, NUMBER O2, DECEMBER 2O17
\end{tabular} 